\title{
Medieval Muslim Cuisine as A Real-Life Foundation for the Meat and Milk Prohibition in Ibn Ezra's Biblical Commentary
}

\begin{abstract}
Abraham Ofir Shemesh
Israel Heritage Department, Ariel University, Kiriat HaMada'a, Ariel 40700, Israel; avrahamos@ariel.ac.il; Tel.: +972-058-7923033

Received: 14 May 2018; Accepted: 23 May 2018; Published: 27 May 2018

Abstract: In his biblical commentary, R. Abraham Ibn Ezra (c. 1090-1164) occasionally voices the contention that the language, culture, and life-style of the Muslim world are capable of contributing to our understanding of contemporary aspects of biblical stories and laws. The current paper deals with the influence of Islamic culinary art in medieval times on Ibn Ezra's Biblical commentary on the meat and milk ban. Ibn Ezra claims that the reality of the Arab kitchen, which includes the Bible lands, preserves the ancient ways of eating. Thus, we can understand the Bible ban in Muslim cuisine. According to the medieval dietary approach, cooking meat and milk is recommended because both products have similar properties. The meat of young goat healthier than lamb meat, so it is common to cook it. Muslims believe that the kid of a goat is better cooked in its own mother's milk, because the two products derive from the same origin.
\end{abstract}

Keywords: biblical commentary; Islamic culinary; Abraham Ibn Ezra; Arab kitchen; kid in its mother's milk; milk and meat; Jewish food; Maimonides; humoralism; doctrine of the four temperaments

\section{Introduction}

R. Abraham Ibn Ezra (c. 1090-1164) was born in Toledo, in Muslim Spain. He lived in Spain for the first five decades of his life, and during this period, he travelled to different countries in North Africa, such as Tunisia, Morocco, and Algeria. Following the occupation of Al-Andalus (Muslim Spain or Islamic Iberia) by the Murābițūn (مر ابطون) tribes in 1090, and then the Al-Mohads (الموحدون (al-Muwaḥidūn 1145, many Jews and Christians, among them Ibn Ezra, were compelled to migrate to Christian countries. For the next three decades he travelled to Christian countries in western Europe-Italy, France, and England-where he utilized the knowledge he had amassed in his youth and adulthood to interpret biblical literature (on Ibn Ezra's date of birth and biography, see (Veizer 1976, pp. 7-51; Levine 1970, pp. 9-46; Melamed 1978, vol. II, pp. 519-20; Kislev 2009, pp. 282-97)). Ibn Ezra, an intellectual and fertile man of science, engaged in varied fields: biblical commentary, linguistics, philosophy, liturgical poems, mathematics, astronomy, and astrology (Zarfati 1968, pp. 130-55; Langermann 1993, pp. 28-85; Goldsstein 1996, pp. 9-21; Sela 1999, pp. 72-85; Sela and Freudenthal 2006, pp. 13-55; Simon 2013).

In several places in his biblical commentary, Ibn Ezra notes the methodological principle whereby the language, culture, and life customs of Muslim society might be used to understand realistic aspects of biblical stories and laws. In his various interpretations, Ibn Ezra presents the following insights:

(1) The customs and material culture of the Arabs reflect biblical reality, since the countries of the Bible, including Eretz Israel, are located in the Arab region, while Christian countries are of a different cultural division and therefore cannot serve as a basis for reaching conclusions concerning life in biblical times ((Ibn Ezra 1976), Long Commentary to Exodus 12: 7; Ibid., 28: 36). 
An example of this interpretative outlook can be found in Ibn Ezra's commentary on Exodus 3: 22. The biblical text relates that before the exodus from Egypt, God instructed Moses to command the Israelite women to borrow silver utensils and clothing items from the Egyptian women: "But each woman shall ask of her neighbor, and of her who sojourns in her house, jewelry of silver and of gold, and clothing, and you shall put them on your sons and on your daughters; thus you shall despoil the Egyptians." This English translation is from the Revised Standard Version (RSV).

This instruction raises the question: Why would the Egyptian women lend the Israelite women valuable possessions? Was this customary? Ibn Ezra, from his personal experience and knowledge of the Muslim culture, claims in his long commentary on this verse that the phenomenon of lending possessions to neighbors, even valuable possessions, is common among Muslim women: "Because it is the women's custom to borrow from their neighbors more than is customary among the men articles of jewelry, gold and silver, to place on the neck of the boys and girls $[\ldots]$ and this is the current-day custom in the land of Ishmael but not in the land of the uncircumcised." Ibn Ezra emphasizes that lending feminine possessions is not customary in Christian countries and therefore knowledge of the Muslim culture and its mannerisms might further clarify the verse (see also Simon 2013, pp. 337-39).

(2) It is not always possible to learn from medieval Arab culture about the biblical era, as from the Arab conquests from the seventh century on, transformations are evident in the conduct practiced in the countries of the Bible. Therefore, in some cases, for example in the matter of the ancient Egyptians' contempt for eating meat, it is necessary to distinguish between the ancient Egyptian culture and inhabitants of the Muslim region who follow the laws of the Quran. Ibn Ezra contends that the reservations of the ancient Egyptians concerning consumption of meat are not relevant for Muslims in contemporary Egypt, and are rather closer to the custom of the Indians-Hindus or Jains-who do not eat meat. He writes: "For all the shepherds are detestable to the Egyptians", indicating that in those days the Egyptians would not eat meat and would not permit a person to sacrifice goats and sheep, as occurs with the people of India today. One who is a shepherd is detested for drinking milk. The people of India do not eat nor drink anything originating from living animals to this day (see (Ibn Ezra 1976), commentary to Genesis 46: 34, and compare to his long commentary to Exodus 8: 22). Indeed, according to the laws of Islam, Muslims are permitted to eat clean meat (halal حَلال). Moreover, eating meat is part of Muslim rituals, for example during Eid al-Adha (عيد الأضحى= the "Sacrifice Feast", which honors the willingness of Abraham sacrifice his son, as an act of obedience to God's command).

(3) In certain cases, ancient cultural continuity was not maintained in Islamic countries and was the reality in Christian Europe that reflected biblical life. One example is beds, which were fairly high. Genesis 49: 29 speaks of Jacob who drew his feet up into the bed before his death. In his commentary on this verse, Ibn Ezra claims that Egyptian beds were high, similar to beds in Christian European countries, which was why Jacob had to draw them up: "He drew his feet up into the bed-because at first he sat on the bed with his feet hanging down as is the custom today in the Edomite countries, not like the beds of the Ishmaelites [=Arabs or Muslims]". Historical sources indeed indicate that medieval European beds, particularly in the homes of the wealthy, were large, wide, and high. These massive beds were usually canopy beds that had posts in their four corners draped with curtains for privacy (on the beds in Europe in Medieval Times see (Diehl and Donnelly 1999, p. 79; Johnston 2011, vol. I, p. 275)).

This paper discusses Ibn Ezra's interpretation explaining the biblical prohibition against eating meat with milk in light of the culinary and medical reality in his time. In the process, I shall discuss the culinary and nutritional conceptions utilized by Ibn Ezra to explain the prohibition based on their sources in the medieval culinary and medical literature of Muslims and Jews. 


\section{The Prohibition of Cooking Meat with Milk-A Review of the Interpretations}

The prohibition against cooking a kid goat in milk is mentioned in the Bible three times, but no reason is given (Exodus 23: 19; Ibid., 34: 26; Deuteronomy 14: 21). Over the generations, commentators, Jewish philosophers, and researchers have offered various explanations for the purpose of the prohibition and its sources. Several Jewish scholars claimed that cooking the meat of a kid goat in its mother's milk is an immoral act and that the purpose of the prohibition is symbolic, to distance one from cruelty and gluttony (Philo 1984, chp. VIII, pp. 249-51; ben Meir 1997, Exodus, p. 58; Ibid., Deuteronomy, p. 189).

Maimonides (R. Moses ben Maimon, Rambam, 1138-1204) claimed that cooking meat in milk is an idolatrous act and that the purpose of the prohibition is to distance one from unacceptable customs (Maimonides 1991, p. 392; ben Gershon 1547, Exodus, p. 98b; Abarbanel 1979, Exodus, p. 218). Others claimed that the prohibition is based on medical/health reasons, as cooking the two foods together produces harmful culinary combinations (Maimonides 1991, p. 392).

Researchers devoted quite a few papers to the reasons for and background of the prohibition as viewed through the Bible and the cultures of the biblical era (Haran 1978, 1979, 1983; Luria 1993; Milgrom 1985; Ratner Robert 1986; Labuschagne 1992; Cooper 2012).

The Scottish anthropologist James George Frazer (1854-1941) claimed that the prohibition stemmed from an aversion (taboo) to certain usages of milk for fear of harm to the cows, because of the sympathetic/magical bond between the animal and its milk (Frazer 1919, vol. III, pp. 118-19, 161-62). Othmar Keel, scholar of Ancient Near Eastern art and its relationship to the biblical text, suggested that cooking meat with milk not only breaches the intimate mental connection between the mother and her young but also symbolically disrupts the expression of divine generosity and cosmic stability manifested in the act of nursing (Keel 1980, pp. 54-141). The Biblical scholar and commentator Moshe David (Umberto) Cassuto (1883-1951) showed that cooking meat with milk was a practice customary in ancient cults, for example that of the Goddess Anat (Cassuto 1958, p. 40; on the Goddess Anat see (Day 1999, pp. 36-43)).

\section{Ibn Ezra's Approach: “The Scriptures Speak of the Present"}

In his long and short commentaries on Exodus 23: 19, Ibn Ezra claims that the reason for the prohibition of cooking meat with milk is educational/moral. Ideologically, the prohibition is included among other restrictions concerning animals that are aimed at preventing cruel human behavior, such as the prohibition against slaughtering an animal and its offspring on the same day (Leviticus 22: 28), or Shiluach ha-Ken, the Jewish law that enjoins one to send away the mother bird before taking her young or her eggs (Deuteronomy 22: 6).

Ibn Ezra discusses several cryptic questions that arise following the biblical wording. In his long commentary on Exodus 23: 19 he writes: "A kid (gedi) is only the son of a goat. And in the Arabic language it means a young goat, and it is not used to designate other species". In other words, the term "kid" (gedi) refers specifically to the young of the domestic goat (Capra hircus mambrica, from the goat antelope subfamily Caprinae and a member of the family Bovidae. The biblical goat (in Hebrew: $e z$ Tע) is clearly identified with the modern-day goat, and the Arabic name as well preserves the goat's ancient name hanz (عَ) or miza (مِنْزَ). The halakhic (halakha means 'Jewish law') prohibition of cooking meat with milk includes in practice the meat of all pure animals. If so, why is it worded as a prohibition against cooking a kid goat in its mother's milk? Moreover, was cooking kid's meat in milk a common culinary phenomenon?

Ibn Ezra's view is that the principle "The scriptures speak of the present", i.e., according to prevalent real-life practice, applies to the wording of the biblical prohibition "a young goat in its mother's milk". Accordingly, the Torah speaks of the cooking of the two products rather than of their unspecified mixing "as it is not the human custom to eat raw meat". Current-day Muslim culinary art attests to the ancient biblical tradition whereby cooking meat, particularly kid's meat, with milk is a 
preferred culinary practice rooted in medical and nutritional conceptions whereby the mixture of these two products is beneficial from various aspects. These are his contentions:

\subsection{In the Muslim Region, Cooked Dishes of Meat with Milk Are Considered Particularly Agreeable}

In his short commentary on Exodus 23: 19 Ibn Ezra says: "And God commanded that the kid not be cooked in its mother's milk, because [to] this day it is the Ishmaelite custom to cook the kid with the milk, and they say that it is an agreeable dish". Namely, Muslim culinary art teaches that kid's meat and milk products are ingredients whose mixture generates a quite tasty and choice product, i.e., a historical continuity is evident with regard to cooking and food preparation as well.

Quite extensive Arabic literature was written in the middle ages on various aspects of contemporary food and nutrition. For example, there are recipe books and instructions for preparing food; Adab (أدب) literature, i.e., (lay) literature in an array of subjects aimed at presenting wide general information required by intellectuals; historical descriptions of how various types of food were consumed by different social classes; the elaborate royal cuisine of the ruling class; and more (on the Muslins' culinary culture see (Arberry 1939, pp. 21-47, 189-214; Rodinson 1949, pp. 95-158; Ashtor 1968, pp. 1017-53; Waines 1989; 1992, pp. 725-38; 2002, vol. II, pp. 216-23; Marin 1994, pp. 205-15; Levanoni 2005, pp. 201-22)).

Did Muslim gourmet diners indeed think that meat and milk is recommended combination? Can an appreciation for the combination of farm raised meat with milk and its products be found in the culinary literature of those days? It appears so. The picture drawn by Ibn Ezra certainly reflects the reality of his time and receives historical support in medieval Muslim cookbooks that praise the cooking of meat with milk, although to date I have found no special reference to the cooking of kid's meat with milk. Before presenting several sources that address dishes combining meat and milk in Muslim cuisine, I must expand on the place of meat and milk products in the culinary art of this cuisine.

The assumption is that combining meat and milk is rooted in the Arab way of life and in agricultural and economic practices of many years. In the Arab-Muslim region, livestock played a major economic role, as sheep and cattle provided a variety of products such as meat, milk and its products, skins, and wool. The animal farm had considerable significance, particularly in semi-arid areas, among migrant shepherd societies which did not cultivate fruit groves or fields.

Milk products were eaten on their own but were also an important ingredient in basic cooking operations of Muslim cuisine, which utilized many animal- and plant-based cooking oils. From the plant world, olive oil and sesame oil were used. The local common breed of sheep, the Awassi (Ovis orientalis platyura aries laticaudata, in Arabic: (عو اسي was utilized to produce fat from the soft tail (in

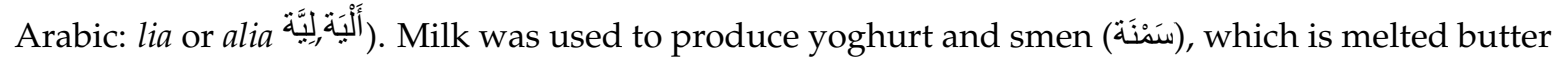
usually melted above boiling water and purified by distillation. Smen is the popular oil of the Middle East and it is used to fry and cook meat and vegetables. Meat and milk combinations in Arab cuisine are strongly associated with smen, as it has a major role in adding flavor to meat dishes (Waines 1991, vol. VI, pp. 807-9). Eating meat was an indication of one's high social class, and only the wealthy and affluent enjoyed this product. Meat dishes were served at festive meals or to guests (Levanoni 2005, pp. 213-17).

The prohibition against cooking meat with milk is mentioned in the Torah in the section on the festivals (Exodus 23: 14-19; Ibid., 34: 22-26), and some have claimed that it is mentioned here because meat is often eaten in festivals as a festive dish, leading to a greater risk of the mixture of meat and milk (Chavel 2006, p. 282). Ibn Ezra, in his long commentary on Exodus 23: 19, states that the prohibition of cooking meat with milk is mentioned in the Torah in close proximity to the festival of Shavuot, as in this season there are young goats and there is a chance that their meat would be cooked in milk: "It was only mentioned with the first fruit, as then the kids abound and grow."

Choice dishes of meat and milk are mentioned in medieval Muslim culinary literature. I shall now bring several examples. The Muslim author Muhammad bin al-Hasan al-Baghdadi (d. 1239/40 
AD) wrote his book "Kitab al-Tabihh" (=The Book of Dishes] (كتاب الطبيخ) on Muslim cuisine in 1226 (on this book see (Nawal 2010, pp. 22-23)). The book was written about 60 years after the death of Ibn Ezra and reflects the culinary reality of which Ibn Ezra speaks in his biblical commentary. Al-Baghdadi devoted a chapter to each of the popular groups of dishes in Muslim cuisine, for example meat dishes and sour dishes. In each chapter he lists the necessary ingredients for preparing the dishes and how they are made.

In the chapter "Milk dishes" he records half a dozen stews of meat and vegetables boiled at length in "Persian milk", which appears to be yoghurt. One of the conspicuous dishes in this group is the madira (مادير), which consists of meat, onions, leeks, and spices. The ingredients are cooked in a pot at length until the liquids evaporate and then mixed with sour yoghurt, mint, and lemon juice and cooked again until thick (Miller 2007, p. 150). Other recipes of meat cooked in milk are customary in traditional Muslim cuisine to this day. One of the most prominent of these is the mansaf (منسف), prepared from rice (or bulgur), mutton, yoghurt, and pine nuts. The mansaf is currently considered a national Jordanian dish, but it is eaten in other parts of the Middle East as well (Basan 2006, p. 70).

\subsection{The Muslims Cook Kid's Meat in Milk Due to the Nutritional/Medical Compatibility of the Two Products}

Humoralism, or the doctrine of the four temperaments, is a nutritional/medical theory originating from the Hellenistic world, utilized in Christian western and Muslim eastern medicine until the 17th century. According to this doctrine, there are four elements (earth, air, fire, and water), four personality types (sanguine, choleric, melancholic, and phlegmatic), and four humors (blood, yellow bile, phlegm, and black bile) in nature and in the human body. The humors reflect one's temperament and nature and also influence one's physical and mental behavior.

The combination of the humors and their relative proportion in the body change from person to person, and this is the source of people's different temperaments; some are phlegmatic (indifferent and slow by nature), choleric (irritable), or melancholic (inclined to depression). Any disruption of the balance between the elements of which the body is constructed or its humors results in illness, while a state of equilibrium is the basis for recovery (on this theory and its application in Medieval medicine see: (Talbot 1978, pp. 391-428).

Muslim doctors influenced by the Hellenistic medical heritage claimed that the way in which food is prepared affects one's temperament and health. How meat is prepared, for example by frying versus cooking, and the ingredients with which it is cooked (for instance vinegar, salt, water, and olive oil) has an effect on the temperament that the meat creates in the human body (Mayer-Chissick 2011, p. 161). In his long commentary on Exodus 23: 19, Ibn Ezra claims that for practical/medical reasons Muslims cook kid's meat in milk, rather than lamb. In general, meat and milk have a different nature and in order to cook them it is necessary to adapt them to each other. It takes more time to cook solid meat than it does milk. Moreover, the meat of different animals has unique features and not all types of meat are suitable for cooking in milk. He writes: "For it is not the custom today in the land of Ishmael to eat lamb cooked in milk, as lamb has in it much phlegm as does milk, and this is harmful and thus is not eaten, and because kid's meat has no phlegm, and when it is young it is hot, kid's meat is cooked in milk".

Aside from the agreeable taste of dishes that include meat and milk, Ibn Ezra is of the opinion that a dish of kid's meat in milk has healthy nutritional qualities. According to Ibn Ezra, judging by the doctrine of temperaments kid's meat is considered "dry" and "hot", while lamb is cold and contains much phlegm. Other medieval doctors voice similar opinions. The Spanish doctor Rabbi Nathan ben Yoel Falaquera, who lived in the second half of the 13th century, writes: "Lamb is very moist and cold and sticky and it has many excesses [="secretions" of unnecessary harmful waste, in Arabic: فضلات]" (Amar and Buchman 2004, p. 127).

This is also stated by the physician and poet Ibn Zuhr of Seville (1094-1162), who said that tzarahar al-ghanam (صَغِير الغَنَ young sheep, i.e., lamb) contains much phlegm and produces excess phlegm in the body (Ibn Zuhr 1992, p. 21). Nonetheless, it is notable that other opinions were also voiced in 
medieval Arab literature. Muslim physician and poet Muhammad ibn Yūsuf Ibn Khalṣun (ابن خلصون), who lived in Andalusia in the 13th century, says that kharuf (خَرُوف = lamb) is very hot (!) and moist and is not suitable for those who have a humid stomach or white bile (Ibn Khalșūn 1996, p. 84).

In any case, Ibn Ezra expresses the outlook that milk is similar in its qualities to lamb and it too has a high level of phlegm. Hence, their combination creates a mixture with considerable phlegm that might create an imbalance in the body and harm it. Kid's meat is more suitable for cooking in milk not only due to their phlegm-related differences but also because of its "hot" temperament while milk is "cold" and thus they balance each other. Due to the excess phlegm in lamb, Arab physicians recommended that it be avoided or that the phlegm be modified by skewer roasting, oven baking, or cooking in vinegar or spices (Ibn Zuhr 1992, p. 21; Ibn Khalșūn 1996, p. 84).

I have found no explicit recommendations by Muslim physicians to combine kid's meat with milk, and there is even an impression that kid's meat is considered fine enough without needing to balance it by cooking. In contrast, medieval culinary literature includes recipes that combine lamb and milk products. For example, an anonymous Andalusian recipe book from the 13th century published by Candida Martinelli includes several recipes of lamb with milk products, such as a dish called Tharida (ثاريدا) that contains lamb, spinach, moist cheese, and butter. In another recipe the author suggests stuffing lamb with cheese and black pepper, cinnamon, onions, and eggs (Martinelli 2012, pp. 43, 86), and some even recommended adding milk products to mutton in certain circumstances.

For example, the Persian physician Muhammad ibn Zakariyyā al-Rāzī's (Rhazes, (865-925) claimed that mutton is "hot" and thus recommended that those who need to "cool" the body cook it in whey (matzal مَصْ ل), sumac (Rhus coriaria), and pomegranate seeds (al-Rāzī 1984, p. 125; and see at length (Nikaein et al. 2012)). Hence, the nutritional/medical outlook expressed by Ibn Ezra was not necessarily accepted by everyone and there were other opinions. It is quite possible that some did not strictly adhere to these views, i.e., there was a discrepancy between theoretical health directives and actual practice.

\subsection{Kid's Meat is Preferable to Lamb as It Is Healthier}

Ibn Ezra further contends that combining milk and kid's meat, rather than the meat of other farm animals, is associated with the positive qualities of this meat:

And do not be surprised that people in these places are not accustomed [should be: are accustomed] to eating the meat of young goats. Because all the physicians admit that no meat equals it, and they even permit it for the sick. It is also eaten in Spain and Africa and Eretz Israel, and Persia, and Babylon. This was also the custom of the ancients, "two choice young goats" (Genesis 27: 9), "we prepare a young goat for you" (Judges 13: 15), and the priest would eat one male goat for a sin offering (Leviticus 6: 19; 23: 19-20).

Ibn Ezra projects from the reality of his time to biblical times. He says that in extensive parts of the Muslim world kid's meat is preferred over other types of meat because it is healthy and choice. Ibn Ezra does not state the nature and qualities of goat milk as perceived by contemporary physicians as he does with regard to the value of kid's meat. In any case, from biblical times goat's milk was considered a food with positive qualities (Book of Proverbs 27: 27). This milk was also preferred in the classical era because it was considered easier to digest (Plinius 1938, Book XXVIII, chp. 33; Preuss 1994, p. 561) and medieval physicians as well indicated its medical benefits (Amar and Buchman 2004, p. 126).

The basis of the outlook presented by Ibn Ezra on the quality of kid's meat is not a norm that developed among the masses, but rather the sweeping support it received among contemporary physicians who recommended it as a routine food and even for the sick. This nutritional/medical view is embedded in the compositions of other medieval physicians of Spanish descent. Maimonides (Spain and Egypt 1138-1204) recommended kid's meat in several of his medical works. In his composition "Aphorisms of Moses" he writes: "The choicest meat originating from four legged animals is pork and 
the closest to it is kid's meat" (Maimonides 1961, p. 230). He writes similarly further on: "Among the meat of all four legged animals kid's meat is unique as it is the choicest" (see Maimonides 1961, p. 239; and compare to Maimonides 1965, pp. 147, 149).

'Abū l-Walīd Muhammad Ibn 'Aḥmad Ibn Rushd (Averroes, Córdoba 1198-1126) claims that kid's meat is preferable to lamb because it is a better producer of kimos, i.e., digestive juices (Ibn Rushd et al. 1987, p. 227). In addition, Rabbi Nathan ben Yoel Falaquera noted his preference for kid's meat: "Kid's meat is moist and average in temperament as it has neither the dryness of the $[=$ mature $]$ goat nor the considerable phlegm of the lamb [ ... ] The meat of the young goat, which is the kid, is average [=in temperament] and it is the choicest of all four-legged animals" (Amar and Buchman 2004, pp. 120, 139)." In another place Falaquera speaks of the inferiority of lamb, and writes: "Lamb [ ... ] is harmful for those with albalgam [in Arabic: البلغ = phlegm, usually white, which is cold and moist] and is more suitable for those with a hot temperament and the gaunt [=because it is cold it is suitable for those with a contrary temperament and not for those with the same temperament]. And in general, the physicians agree that it is a harmful food" (Amar and Buchman 2004, p. 127. On the differences between kid and lamb according to the doctrine of temperaments, see also Mayer-Chissick 2011, pp. 164-69).

Ibn Ezra cites several verses as proof that in biblical times people preferred the meat of kid goats to that of other farm animals, as customary in his own time. Rebecca cooked young goats for Isaac (Genesis 27: 9), Manoach's wife suggests to the angel that she cook him a young goat (Judges 13:15), and the priests too ate a kid goat as a sin offering in the tabernacle (Leviticus 6: 19; 23: 19-20). Notably, the kid goat is not specifically characteristic of the priests' food and this is certainly not indicated by the sin offering. In the same way, other types of animals were also mentioned as offerings and were eaten by the priests. The verses also seem to indicate lay consumption of other farm animals, such as the "calf" (ben bakar, Genesis 18: 7) or "fattened calf" (egel marbek 1 Samuel 28: 24), however he may not see these as proof because they speak of hospitality situations that do not indicate a routine custom. Moreover, even the verses that refer to ritual settings (Leviticus 6: 19; 23: 19-20) are no proof, as the Israelite rituals included a variety of farm animals.

It is to be assumed that kid goats were suitable for slaughtering and eating in the home and with the family for two reasons: kid's meat is soft and due to the fairly small size of the animal it does not require lengthy preservation in the absence of refrigeration. When slaughtering a kid goat for one's family no pieces of meat are left over, which might rot. The impression is that Ibn Ezra uses the nutritional/medical attitude to kid's meat in his own time to learn about biblical times, although in practice the ancients might have preferred this meat for other reasons.

\subsection{Kid's Meat Is Particularly Well Suited for Cooking in Its Mother's Milk}

Ibn Ezra further explains why the Torah mentioned cooking a kid goat in its mother's milk and not in milk in general. He says that it is recommended to cook a kid goat specifically in its mother's milk because the combination of the two may produce a more choice culinary result than cooking in the milk of other goats, and certainly of other farm animals. He writes: "And the Ishmaelites too agree that if the kid is cooked in its mother's milk, which comes from the same source, then it is more enjoyable, and the Scriptures speak of the present." The assumption is that the young or products that originate from an animal (or human being) naturally bear similar qualities to their source.

The affinity between the qualities of the newborn to its mother particularly among human beings, among other things due to consuming its mother's milk, was expressed by Rabbenu Behaye ben Asher Ibn Haliwa (Spain 1250-1340). He writes: "As the fetus is formed from the menstruation blood and grows in its mother's stomach for a set amount of time, and after it is born and enters the world it nurses from its mother's breasts, so it its nature is necessarily linked with the mother's nature more than with the father's" (Behaye 1994, Leviticus 24: 11). Moreover, two products that are affiliated with a shared source bear its qualities and thus might mix well, in our case the meat of the kid goat and the milk originating from its mother. 
Ibn Ezra adds that understanding the verse "Do not cook a young goat (gedi) in its mother's milk" (Exodus 23: 19) as indicating specifically a kid goat is justified by the Arabic. He objects to the famous Medieval commentator of the Bible, Rabbi Shlomo Yitzchaki's (Rashi, North France 1040-1105), understanding that the word gedi is a collective noun designating young individuals of all pure domestic animals (goats, sheep, cows). Rashi's interpretation is based on the Mishna and Talmud ${ }^{1}$ in Bavli Hulin 113a that the meat of any pure animal must not be cooked in milk (of a pure animal), not only the meat of a goat.

The Talmud reaches this conclusion from the two words "young goat" (gedi izim) in the story of Judah and Tamar in Genesis (38: 17-20). There mention is made specifically of a young goat, indicating that in other places that mention an unspecified gedi (young animal) the meaning is more general and wide (see Mishna Hulin 8: 4 and in the Talmudic discussion there, 113a-b). However, the fact that only young goats are mentioned in the Bible and not "young sheep" creates doubts as to this understanding (the couple words gedi izim is mentioned in the Tora more times. See for example: Judges 6: 19; Ibid., 13: 15; Ibid., 15: 1; 1 Samuel 16: 20). Notably, Ibn Ezra does not object to the rabbinical view that the prohibition includes the milk and meat of all other domestic animals, but according to his understanding the Torah used the word gedi because it is a popular animal used for consumption and preferred over other farm animals.

Ibn Ezra claims that in the Arabic language, which is close to the language of the Bible (on the affinity between Hebrew and Arabic in Ibn Ezra commentary see Genesis 30: 37; Leviticus 11: 13), gedi serves to designate only a young goat, while the young of other domestic animals have different designations, and this is evident from the words of other medieval grammarians as well:

1. According to the Jewish grammarian and lexicographer Judah ibn Kuraish (Tiaret, North Africa, ninth century), in Arabic the word for gedi is gadi (جَ), and for a young goat (gedi izim)—gadi anz (see also Ibn Kuraish 1984, p. 245).

2. The Arabic word for lamb (in Hebrew: taleh) is tali (طَّلَّ) (Ibn Kuraish 1984, p. 156). In contemporary Arabic the lamb is also called: خَخَل ,خَرُوف , خَخْوف) and the word kharuf has also the meaning of mature sheep.

3. A calf (in Hebrew: egel) is called 'ajel (عَجْ) (Ibn Kuraish 1984, p. 330).

Ibn Ezra explains that the terms gedi and gedi izim and alternately se'ir and se'ir izim refer to the same species at different stages of development. Gedi izim is a young goat that needs its mother and is thus affiliated with her, while gedi alone is an animal that is older but still not mature.

\subsection{The Concern of Cooking Meat with Milk Arises Due to the Common Method of Marketing Milk Produce}

Based on the manner in which goats were milked and the produce marketed in medieval times, Ibn Ezra explains that the concern that a kid's meat might be cooked in its mother's milk exists not only when these are in the possession of the kid's owner. He says that livestock owners milk all the females they own and mix the milk together to sell in the market. Thus, it is possible that a person who purchased a kid for its meat might also purchase its mother's milk. This is indeed an unlikely concern but when dealing with a prohibition from the Torah one must take all precautions: "And most people who have no sheep and goats are accustomed to buying their milk in the market, and the milk is collected from many sheep. The kid's buyer may not know the location of its mother, and if he bought milk maybe the milk includes that of the kid's mother and he will commit a transgression.

1 The Mishna ('repeated study') was redacted by R. Judah the Prince at the end of the second century CE. The Mishna is the first major written redaction of the Jewish oral traditions and laws. The Talmud (also Gemara, means 'study' or 'learning') is a collection of commentaries on and elaborations of the Mishnah and certain auxiliary materials. The term 'Talmud' refers to the Jerusalem Talmud (Talmud Yerushalmi) which was compiled in the Land of Israel (c. $400 \mathrm{CE}$ ), and the collection known as the Babylonian Talmud (Talmud Bavli), compiled by the scholars of Babylonia (c. 500 CE). 
And where there is any doubt concerning prohibitions from the Torah a stringent approach is taken" (The Long Commentary to Exodus 23: 19).

Jeffrey Tigay claimed that on principle such a concern might arise in small villages where there is no separation between the meat and milk industries. A farmer who runs an animal farm sells the meat of the farm animals and also their milk produce in the local market and therefore there was a reasonable chance that a buyer would purchase meat and milk from the same mother (Tigay 1996, pp. 140-41).

\section{Discussion and Conclusions}

The paper discusses the impact of medieval Muslim culinary practices on Ibn Ezra's interpretations of the biblical prohibition against cooking a kid in its mother's milk. Ibn Ezra's basic conception is that the common reality in the Muslim region, which includes the countries of the Bible, usually preserves ancient ways of life, and thus we can utilize it to understand the restriction of eating meat and milk that have been cooked together. Ibn Ezra's point of departure is that the combination of these two products in a culinary setting is not a random occurrence, but rather a common practice. The combined use of these products follows a lengthy tradition within regional cuisine that was preserved in the Islamic region, which includes a migrant/economic element of raising animals and utilizing their produce (meat and milk products). Ibn Ezra's contentions are supported by contemporary cookbooks, for example recipes taken from the castle kitchens of Muslim caliphs. Meat and milk were mixed in preparing choice and elegant dishes as well as in festive meals and banquets.

Throughout history, several explanations and justifications were offered for the prohibition of cooking meat with milk. Ibn Ezra explains the basis for the Torah's specific prohibition of cooking a kid goat in its mother's milk rather than meat in milk in general, as was later accepted in practice in Jewish law, using several culinary and medical views popular among the Muslims:

1. It is not customary to eat raw meat, therefore the Torah speaks specifically of cooking.

2. Cooking kid's meat, rather than any other type of meat, in milk is rooted in the nutritional/medical compatibility of the two products.

3. The Torah mentions kid's meat specifically due to its preference over lamb and medieval practice proves that it was a more popular food.

4. The reference to cooking in the mother's milk rather than in milk in general is also justified, as explained by the Muslim understanding.

According to this, kid's meat is more suitable for cooking specifically in its mother's milk because they both come from the same source and therefore their combination produces a more agreeable dish. In light of the fact that this combination was a recommended one in his time, Ibn Ezra admits that he does not understand the reason for the prohibition but he nonetheless offers an explanation: "And we have no need to seek the reason for the prohibition, as it is not known to the wise. It may be that it is a cruelty of the heart" (The Long Commentary to Exodus 23: 19).

A point worthy of attention is the scientific foundations of Ibn Ezra's nutritional-medical explanations. In his biblical commentary Ibn Ezra presents the qualities of mixed meat and milk dishes as well as other elements not discussed here. For example, his discussion of the approach whereby eating bitter herbs with the Passover offering on the night of the exodus from Egypt involved a medical need related to the humid air in Egypt (The Long Commentary to Exodus 12: 8). Ibn Ezra is not known as a physician, although some attribute to him the writing of medical works (Leibowitz 1966, p. 248). His explanations of the prohibition against cooking meat with milk are based on the principles of Greco-Roman medicine (the doctrine of the four temperaments) that formed the basis for medieval diagnosis and treatment, and the views he voices can be found among other physicians of his era, proof of his current knowledge in the nutritional/medical field. 
In fact, the basis for Ibn Ezra's interpretation that "the Scriptures speak of the present" appears in earlier ancient sources, but he applies it to the reality of his times. The argument that the Torah mentioned a "kid" because it is customary to eat kid's meat specifically appears in Mekhilta deRabbi Ishmael, which is a tannaitic ${ }^{2}$ midrash halakha on the book of Exodus: "Do not cook a young goat in its mother's milk, it says only young goat, from where do we learn about all other animals? The Scriptures speak of the present" (Horovitz and Rabin 1931, p. 21). This principle was brought in several midrashic and halakhic sources adjacent to Ibn Ezra's time, for example in the Pesikta Zutrata composed by R. Tuvya ben Eliezer in the 11th century (Buber 1880, Exodus 23: 19) and in the 12th century by Maimonides ((Maimonides 2002), hilchot ma'achalot asurot [=laws of forbidden foods] 9: 3). Nonetheless, it appears that Ibn Ezra was among the few to explain the meaning of the principle and to lend it validity and relevance in view of contemporary practices.

Ibn Ezra claimed that the preference for cooking kid's meat in milk in his period stemmed from health reasons. However, some suggested otherwise. R. Shmuel ben Meir (Rashbam, 1080-1160) links this to economic considerations related to the ancient autarkic farm. In his commentary on Exodus 23:19 he writes: "It is the manner of the goats to give birth to two kids at a time, and people would slaughter one of them, and since most milk [comes from] goats they would cook it in the mother's milk, and the Scriptures speak of the present" (ben Meir 1997, p. 58). Namely, a goat usually gives birth to two kids (the litter usually includes one or two kids, but the birth of twins is common in goats, see (Alon 1990, p. 238)); one is eaten and the other is used to maintain the flock (for meat or breeding). He says that much of the milk was produced from goats rather than sheep, and therefore kid goats were usually cooked in goat milk. However, Rashbam, who lived in distant Europe, had no idea of the reality in Eretz Israel in his own time nor in biblical times, so it is to be assumed that his commentary is based on practices familiar to him.

Conflicts of Interest: The author declares no conflicts of interest.

\section{References}

Abarbanel, Isaac ben Judah. 1979. Commentary on the Torah. Jerusalem: Hotza'at Sefarim Bene Arbael.

Alon, Azaria. 1990. XII: Plants and Animals in Human's Farm. In Plants and Animals of the Land of Israel: An Illustrated Encyclopedia. Tel Aviv: Ministry of Defense.

al-Rāzī, Muhammad ibn Zakariyyā (Rhazes). 1984. Manfe' al-Aghzie va daf-o-Mazareha (Benefits of Food and its Harmfulness). Damascus: Damaski Press.

Amar, Zohar, and Yael Buchman. 2004. Sori Haguf by R. Nathan Ben Yoel Falaquera. Tel Aviv: Oren Hafakotot Dfus. Arberry, Arthur J. 1939. A Baghdad Cookery Book. Islamic Culture 13: 21-47, 189-214.

Ashtor, Eliyzhu. 1968. Essai sur l'alimentation des diverses classes social dans l'Orient medieval. Annales 23: 1017-53. [CrossRef]

Basan, Ghillie. 2006. The Middle Eastern Kitchen: A Book of Essential Ingredients with Over 150 Authentic Recipes. New York: Hippocrene Books.

Behaye, ben Asher Ibn Halawa. 1994. Commentary on the Torah. Jerusalem: Mishor.

ben Gershon, Levi. 1547. Commentary on the Torah. Venice: Daniel Bomberg.

ben Meir, Shmuel. 1997. Commentary on the Torah, Torat Haim Edition (Exodus, II). Jerusalem: Mossad ha-Rav Kook. Buber, Solomon. 1880. Pesikta Zutrata (Lekach Tov). Vilna: Reem.

Cassuto, Umberto Moshe David. 1958. The Goddess Anath: Canaanite Epics of the Patriarchal Age. Jerusalem: Bialik Institute.

Chavel, Haim D. 2006. The Commentaries of Hizkuni on the Tora. Jerusalem: Mosad ha-Rav Kook. Cooper, Alan. 2012. Once Again: Seething a Kid in Its Mother's Milk. JSIJ 10: 109-43.

2 Tannaim, i.e., "repeaters" or "teachers" are the rabbinic sages whose views are recorded in the Mishnah, from approximately $10-220$ CE. 
Day, Peggy L. 1999. Anat. In Dictionary of Deities and Demons in the Bible (DDD), 2nd ed. Edited by Karel van der Toorn, Bob Becking and Pieter W. van der Horst. Leiden: Brill, pp. 36-43.

Diehl, Daniel, and Mark P. Donnelly. 1999. Medieval Furniture: Plans and Instructions for Historical Reproductions. Mechanicsburg: Stackpole Books.

Frazer, James George. 1919. Folk-Lore in the Old Testament: Studies in Comparative Religion Legend E Law. London: Macmillan and Co.

Goldsstein, Bernard R. 1996. Astronomy and Astrology in the Works of Abraham ibn Ezra. Arabic Sciences and philosophy 6: 9-21. [CrossRef]

Haran, Menahem. 1978. Kid in its Mother's Milk. Eretz Israel 14: 12-18.

Haran, Menahem. 1979. Seething a Kid in its Mother's Milk. JJS 30: 23-35. [CrossRef]

Haran, Menahem. 1983. A Kid in its Mother's Milk and a kid sucks its Mother's Milk. Tarbitz 52: 371-92.

Horovitz, Haim Saul, and Israel Abraham Rabin. 1931. Mekhilta de Rabbi Ishmael. Frankfurt am Main: J. Kauffmann. Ibn Ezra, Abraham. 1976. Ibn Ezra: Commentary on the Torah. Edited by Asher Veizer. Jerusalem: Mosad ha-Rav Kook. Ibn Khalṣūn, Muhammad ibn Yūsuf. 1996. Kitāb al-Ağdíliya (كتاب الأغذية). Damascus: Ma had al-Faransī lil-Dirāsāt al-'Arabīyah.

Ibn Kuraish, Judah. 1984. The Risalah of Judah ibn Kuraish. Edited by Dan Beker. Tel Aviv: Tel Aviv University.

Ibn Rushd, 'Abū l-Walīd Muhammad Ibn 'Aḥmad Ibn Rushd (Averroes), J. M. Fórneas Besteiro, and Camilo Alvarez de Morales y Ruiz-Matas, eds. 1987. Kitab al-Kulliyat fi al-Tibb الكَّيات في الطب)=General Principles of Medicine). Madrid: Madrasat al-Dirāsāt al-'Arabīyah bi-Gharnāțah, Madrīd, al-Majlis al-A'lá lil-Buhūth al-'Ilmīyah, Consejo Superior de Investigaciones Científicas.

Ibn Zuhr, Abu Marwan Abd al-Malik. 1992. Kitab al-Agdiya. Madrid: Consejo Superior de Investigaciones Científicas, Instituto de Cooperación con el Mundo Árabe.

Johnston, Ruth A. 2011. All Things Medieval: An Encyclopaedia of the Medieval World. Santa Barbara: Greenwood, vol. 1.

Keel, Othmar. 1980. Das Böcklein in der Milch Seiner Mutter und Verwandtes: Im Lichte Eines Altorientalischen Bildmotivs (OBO 33). V.IRAT III-KEE 1980.1, (Böcklein). Freiburg: Universitätsverlag; Göttingen: Vandenhoeck und Ruprecht.

Kislev, Itamar. 2009. The Relationship between the Pentateuch Commentaries Composed by R. Abraham Ibn Ezra in France and the Significance of this Relationship for the Biographical Chronology of the Commentator. Journal of Jewish Studies 60: 282-97. [CrossRef]

Labuschagne, Casper Jeremiah. 1992. 'You Shall not Boil a Kid in Its Mother's Milk': A New Proposal for the Origin of the Prohibition. In The Scriptures and the Scrolls: Studies in Honour of A. S. van der Woude on the Occasion of His 65th Birthday (SVT 49). Edited by Garcia Martinez, Antonius Hilhorst and Casper J. Labuschagne. Leiden: Brill, pp. 6-17.

Langermann, Tzvi Y. 1993. Some Astrological Themes in the Thought of Abraham ibn Ezra. In Rabbi Abraham ibn Ezra: Studies in the Writings of a Twelfth-Century Jewish Polymath. Edited by Isadore Twersky and Jay M. Harris. Cambridge: Harvard University Press, pp. 28-85.

Leibowitz, Jehoshua. 1966. Eyes diseases in "Sefer ha-Nisyonot" with attributed to Abraham Ibn Ezra. ha-Refuah 70: 248-49.

Levanoni, Amalia. 2005. Food and Cooking during the Mamluk Era: Social and Political Implications. Mamluk Studies Review 9: 201-22.

Levine, Israel. 1970. Abraham Ibn Ezra: His Life and His Poetry. Tel Aviv: HaKibbutz HaMehuchad.

Luria, Ben Zion. 1993. Do not seethe a Kid in its Mother's Milk. Bet Mikra 38: 72-75.

Maimonides, Moses. 1965. Medical Responsa by Maimonides. Edited by Süssmann Muntner. Jerusalem: Mossad ha-Rav Kook.

Maimonides, Moses. 1961. Medical aphorisms of Moses Maimonides. Edited by Süssmann Muntner. Jerusalem: Mossad ha-Rav Kook.

Maimonides, Moses. 1991. The Guide for the Perplexed (More Nevochim). Edited by Yosef Kaphach. Jerusalem: Mosad ha-Rav Kook.

Maimonides, Moses. 2002. Mishneh Torah. Edited by Shabtai Frankel. Jerusalem and Benei-Brak: Hotza'at Shabse Frankel LTD. 
Marin, Manuela. 1994. Beyond Taste: The Complements of Colour and Smell in the Medieval Arab Culinary Tradition. In Culinary Cultures of the Middle East. Edited by Sami Zubaida and Richard Tapper. London: Tauris Parke, pp. 205-14.

Martinelli, Candida, trans. 2012. 13th Century. Anonymous Andalusian Cookbook: Kitab al tabikh fi-1-Maghrib wa-l-Andalus fi 'asr al-Muwahhidin, li-mu'allif majhul. The Book of Cooking in Maghreb and Andalus in the era of Almohads, by an unknown author. Available online: http:/ /italophiles.com/andalusian_cookbook. pdf (accessed on 10 May 2018).

Mayer-Chissick, Uri. 2011. Food and Balance: Nutrition from Theory to Practice, According to the Humoural System. In the Muslim-Arab Empire between the 9th and the 16th Centuries. Ph.D. dissertation, University of Haifa, Haifa, Israel.

Melamed, Ezra Zion. 1978. Biblical Commentaries: Their Methods and Approaches. Jerusalem: Magnes Press and Hebrew University.

Milgrom, Jacob. 1985. "You Shall Not Boil a Kid in Its Mother's Milk": An Archaeological Myth Destroyed. Bible Review 113: 48-55.

Miller, H. Daniel. 2007. Pleasures of Consumption: The Birth of Medieval Islamic cuisine. In Food: The History of Taste. California Studies in Food \& Culture. Edited by Paul H. Freedman. Berkeley: University of California Press.

Nawal, Nasrallah. 2010. Annals of the Caliphs' Kitchens: Ibn Sayyār al-Warrāq's Tenth-Century Baghdadi Cookbook. Leiden: Brill.

Nikaein, Farzad, Arman Zargaran, and Alireza Mehdizadeh. 2012. Rhazes' concepts and manuscripts on nutrition in treatment and health care. Ancient Science of Life 31: 160-63. [PubMed]

Philo. 1984. On the Virtues. Translated by Francis Henry Colson. Cambridge: Loeb Classical Library, Harvard University Press.

Plinius. 1938. Naturalis Historia. Translated by Horace Rackham. London: Loeb Classical Library.

Preuss, Julius. 1994. Biblical and Talmudic Medicine. Translated by Fred Rosner. Northvale: J. Aronson.

Ratner Robert, Bruce Zuckerman. 1986. A Kid in Milk? New Photographs of KTU 1.23, Line 14. HUCA 57: 15-60.

Rodinson, Maxime. 1949. Recherches sur documents arabes relatifs à la cuisine. Revue des Etudes Slamiques 17: 95-158.

Sela, Shlomo. 1999. Astrology and Biblical Exegesis in the Thought of Abraham Ibn Ezra. Ramat Gan: Bar-Ilan University.

Sela, Shlomo, and Gad Freudenthal. 2006. Abraham Ibn Ezra's Scholarly Writings: A Chronological Listing. Aleph 6: 13-55. [CrossRef]

Simon, Uriel. 2013. "The Ear Discerns Words"- Studies in Ibn Ezra's Exegetical Methodology. Ramat Ban: Bar Ilan University Press.

Talbot, Charles H. 1978. Medicine. In Science in the Middle Ages. Edited by David C. Lindberg. Chicago: University of Chicago Press, pp. 391-428.

Tigay, Jeffrey H. 1996. Deuteronomy: JPS Torah Commentary. Philadelphia: Jewish Publication Society.

Veizer, Asher. 1976. Abraham Ibn Ezra: Commentary on the Torah. Jerusalem: Mosad Harav Kook.

Waines, David. 1989. In a Caliph's Kitchen: Mediaeval Arabic Cooking for the Modern Gourmet. London: Riad El-Rayyes Books Ltd.

Waines, David. 1991. Matbakh. In The Encyclopedia of Islam, 2nd ed. Edited by Clifford Edmund Bosworth, E. van Donzel, Bernard Lewis and Charles Pellat. Leiden: Brill, vol. VI, pp. 807-9.

Waines, David. 1992. The Culinary Culture of al-Andalus. In The Legacy of Muslim Spain. Edited by Salma Khadra Jayyusi. Leiden: Brill, pp. 725-38.

Waines, David. 2002. Food and Drink. In The Encyclopedia of the Qur'an. Edited by Jane Dammen. Leiden and Boston: Brill, vol. II, pp. 216-23.

Zarfati, Gad ben Ami. 1968. Mathematical Terminology in Hebrew Medieval Scientific Literature. Jerusalem: Magnes Press, Hebrew University.

(C) 2018 by the author. Licensee MDPI, Basel, Switzerland. This article is an open access article distributed under the terms and conditions of the Creative Commons Attribution (CC BY) license (http:/ / creativecommons.org/licenses/by/4.0/). 